BY CHARLES H. GREENE, BARBARA A. BLOCK, DAVID WELCH,

GEORGE JACKSON, GARETH L. LAWSON, AND ERIN L. RECHISKY

\title{
Advances in \\ Conservation Oceanography \\ New Tagging and Tracking Technologies and Their Potential for Transforming the Science Underlying Fisheries Management
}

ABSTRACT. Overexploitation of living resources and climate change are among the most obvious global-scale impacts of human society on marine ecosystems. In an age of such large-scale anthropogenic impacts, marine scientists, resource managers, and policymakers must rethink their approaches to protecting and managing marine populations and ecosystems. Conservation oceanography is an emerging field of science that incorporates the latest advances in ocean science and technology to provide resource managers and policymakers with the information they need to ensure the sustainability of the marine environment and its living resources. Here, we discuss the historical context of conservation oceanography as it applies to marine fisheries management. We then describe two projects, one focused on Atlantic bluefin tuna and the other on Pacific salmon, that illustrate the potential of new tagging and tracking technologies for transforming the science underlying fisheries management.

\section{INTRODUCTION}

During the past half century, overfishing in many parts of the global ocean has had a substantial impact on predators at or near the top of the marine food chain (Myers and Worm, 2003; Sibert et al., 2006). In some regions, fisheries have responded by shifting their efforts to species further down the food chain (Pauly et al., 1998; Essington et al., 2006). In addition, overfishing has blurred what the baseline conditions for many coastal ecosystems were like prior to human exploitation (Pauly, 1995; Jackson et al., 2001; Lotze et al., 2006), further complicating the setting of stock recovery goals. Recognition of these past impacts of overfishing, combined with the current overexploited status of many fish stocks, has encouraged a shift in fisheries 
management from a single-species approach, focused on maximizing yield, to an ecosystem-based approach, focused on rebuilding depleted fish stocks while protecting and restoring impacted ecosystems (Pauly et al., 2002; US Commission on Ocean Policy, 2004). In a global ocean responding to both fishing pressures from the top down and climate forcing from the bottom up (Frank et al., 2006; Cury et al., 2007; Greene and Pershing, 2007; Greene et al., 2008), such an ecosystem-based approach to fisheries management cannot continue to rely primarily on the same catch and survey data traditionally collected to support the single-species approach. Instead, a more dynamic framework for the science is needed, one that builds upon our technological capacity to monitor marine living resources in their natural environment. Conservation oceanography can provide the new concepts and tools for such a framework, enabling scientists to quantify and forecast the behavioral, physiological, and ecological responses of fish populations to changes in their ocean environment. The technological bases for this transformation can be found in recent advances in miniaturized physiological and environmental sensors, animal tracking techniques, ocean-observing systems, and computer models that assimilate biological and environmental data rapidly after collection (Sibert and Nielson, 2001; Block et al., 2003; Special Issue on Ocean Observations, Oceanography 16(4), 2003; Welch et al., 2003; Block, 2005; Block et al., 2005; Cooke et al., 2008). All of these technologies are in relatively early stages of development; hence, there is considerable scope for growth as the field of conservation oceanography matures.

\section{HISTORICAL CONTEXT}

The roots of fisheries-associated conservation oceanography can be traced back to the first half of the twentieth century, when one of the principal goals of ocean scientists was to enhance the yield of commercially exploited fish stocks by improving our understanding of the ocean environment and its natural variability. To promote this agenda, scientific organizations, such as the International Council for the Exploration of the Sea (Rozwadowski, 2002), were founded, and ocean monitoring programs, such as the Continuous Plankton Recorder Survey (Reid et al., 2003), were initiated. Unfortunately, the ocean proved to vary greatly in both space and time, and the resources and technologies necessary to adequately sample and model such a highly variable environment were not available.

After the two world wars, it became clear that commercial harvesting was having an impact on fish population dynamics that was at least comparable single-species stock-recruitment models that largely ignored environmental variability (Schaefer, 1954; Ricker, 1954). This approach to fisheries management avoided the problem of quantifying the ocean's environmental variability by assuming that it could be averaged out when determining the stock-recruitment relationship. The El Niño-related collapse of the Peruvian anchovy fishery during the early 1970s was the first of many failures in single-species fisheries management that suggested the fallacy of this assumption (Larkin, 1977).

As many fish stocks around the world continued to fluctuate wildly throughout the 1970s and 1980s, with poor recruitment years generally outnumbering good ones, a renewed effort was made to incorporate studies of ocean processes into fisheries research. The field of fisheries oceanography emerged at this time, and many field, laboratory, and modeling studies have been conducted since then to investigate the physical and biological processes affecting survivor-

\section{$S$ CONSERVATION OCEANOGRAPHY IS AN EMERGING FIELD OF SCIENCE THAT INCORPORATES THE LATEST ADVANCES IN OCEAN SCIENCE AND TECHNOLOGY TO PROVIDE RESOURCE MANAGERS AND POLICYMAKERS WITH THE INFORMATION THEY NEED TO ENSURE THE SUSTAINABILITY OF THE MARINE ENVIRONMENT AND ITS LIVING RESOURCES.}

to the effects of the ocean environment's natural variability. During the 1950s, fisheries management entered a period in which catch limits were set to maximize sustainable yields on the basis of ship during the early life history stages of fish (Kendall and Duker, 1998; Govoni, 2005). Since the 1980s, advances in computational methods have enabled scientists to develop individual-based 
models that can be used to study the ecology of larval and juvenile fishes in their advective environment (Miller, 2007; Werner et al., 2007). Although such individual-based models are capable of simulating and exploring the range of theoretical possibilities arising from different scenarios of interacting physical and biological processes, the limited ability of scientists to track the movements as well as behavioral and physiological responses of individual animals in situ has constrained the conclusions that can be drawn from these studies (Gawarkiewicz et al., 2007).

\section{RECENT TECHNOLOGICAL}

\section{ADVANCES}

Recent advances in animal tagging and tracking, using electronic tags and miniaturized sensor technologies, have introduced new capabilities for studying the ecological dynamics of marine animals in the wild. These technological advances, which have enabled scientists to track individual animals over vast areas of the ocean (Kitigawa et al., 2000; Gunn and Block, 2001; Sibert and Nielson, 2001; Wilson et al., 2001; Block et al., 2003; Welch, 2003; Block, 2005; Weng et al., 2005) while simultaneously

Charles H. Greene (chg2@cornell.edu) is Director, Ocean Resources and Ecosystems Program, Cornell University, Ithaca, NY, USA. Barbara A. Block is the Charles and Elizabeth Protho Professor in Marine Sciences, Department of Biology, Hopkins Marine Station, Stanford University, Pacific Grove, CA, USA. David Welch is CEO, Kintama Research Corporation, Nanaimo, British Columbia, Canada. George Jackson is Senior Lecturer, Institute of Antarctic and Southern Ocean Studies, University of Tasmania, Hobart, Tasmania, Australia, and Project Leader, Pacific Ocean Shelf Tracking Project, Vancouver Aquarium, Vancouver, British Columbia. Gareth L. Lawson was Postdoctoral Research Associate, Department of Biology, Hopkins Marine Station, Stanford University, Pacific Grove, CA, USA and currently is Assistant Scientist, Biology Department, Woods Hole Oceanographic Institution, Woods Hole, MA, USA. Erin L. Rechisky is PhD Candidate, Fisheries Centre, University of British Columbia, Vancouver, British Columbia, Canada. drifters, and gliders (Perry and Rudnick, 2003). Models that can assimilate the four-dimensional data derived from satellites and ocean-observing systems will enable scientists to characterize the ocean's environmental variability in a manner few could have imagined only a decade ago. Although the ocean will continue to be undersampled in both space and time for many years to come, data-assimilation methods are allowing scientists to steadily bridge the gap between actual environmental conditions in the real world and those simulated in models of marine ecosystems (Rothstein et al., 2006). Developing more sophisticated models that incorporate the movements of individual animals in their time-varying, three-dimensional environments will be vital to addressing many of the needs in ecosystem-based management.

\section{FISH TALES FROM}

\section{TWO OCEANS}

To illustrate some of the recent advances in conservation oceanography, we describe two ongoing projects, Tag-AGiant (TAG) in the North Atlantic and Pacific Ocean Shelf Tracking (POST) in the North Pacific. The TAG project focuses on tagging and tracking northern bluefin tuna (Thunnus thynnus), while the POST project focuses primarily, but not exclusively, on tagging and tracking a variety of Pacific salmonid species (Oncorhynchus spp.).

\section{Tag-A-Giant Project}

Atlantic bluefin tuna are very valuable, with sushi-grade giant tuna typically fetching $\$ 15,000$ or more per fish at the Tsukiji Wholesale Seafood Market in Tokyo. Considered overexploited since 
1982, this species continues to be harvested at high rates throughout the North Atlantic despite dramatic declines in the adult breeding populations on both sides of the basin. The Atlantic bluefin tuna fishery is regulated by the International Commission for the Conservation of Atlantic Tunas (ICCAT). ICCAT manages bluefin tuna as two separate management units, one in the western Atlantic with a breeding area in the Gulf of Mexico, and the other in the eastern Atlantic with a breeding area in the Mediterranean Sea. The western Atlantic Gulf of Mexico breeding population has declined by over $80 \%$, which led to a reduction in fishing quotas off North America beginning in 1981 and the implementation of a fishery recovery plan in 1998. To date, the population has not recovered, and calls have arisen for listing the Atlantic bluefin tuna as an endangered species and placing a moratorium on its harvest (Safina and Klinger, 2008). Quotas in the eastern Atlantic have been considerably higher, with actual catches far exceeding allocated quotas. No credible recovery plan has been implemented in the eastern Atlantic to assure the longterm survival of this species.

The TAG project uses a combination of surgically implanted archival tags and externally attached pop-up satellite archival tags (PATs) to study the movements, behavior, population structure, and physiological ecology of Atlantic bluefin tuna (Figure 1a-d). Both types of tags sense and archive the pressure, external temperature, and ambient light experienced by individual bluefin tuna; the implanted tags also record internal temperatures measured inside the tuna's peritoneal cavity (Block et al., 1998, 2001; Teo et al., 2007b). Implanted tags

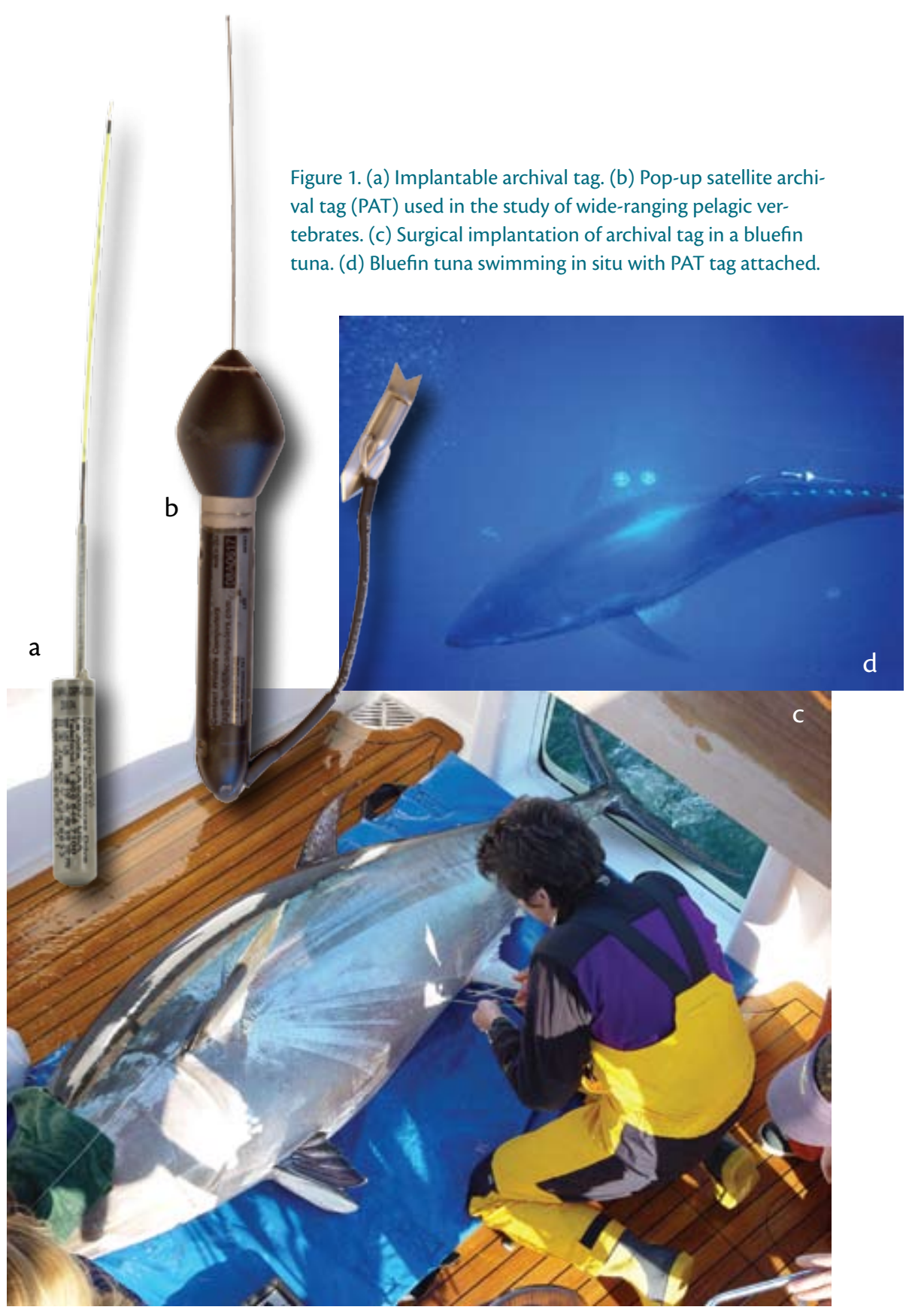

can collect data for multiple years, but must be recovered from fish recaptured by the tuna fishery in order to obtain the archived data. A generous reward to fisherman for returning tags has resulted in over $20 \%$ of them being recovered to date (Block et al., 2005; Kurota et al., in press). In contrast to the implanted tags, PATs can collect data for one year, but do not require that fish be recaptured. Instead, each PAT is programmed to release at a set time via electrolysis of a metal wire attaching the tag to a dart embedded in the fish. Once released, the PAT floats to the surface where it transmits a summary of its archived data set to the ARGOS satellite system.

The ambient light and external temperature data from both types of archival tags are used to estimate geolocations, which in turn are used to reconstruct daily movement patterns (Teo et al., 2004; Nielsen et al., 2006). Longitudes and latitudes are estimated by using the light data, collected to reconstruct daily sunrise and sunset curves, in 

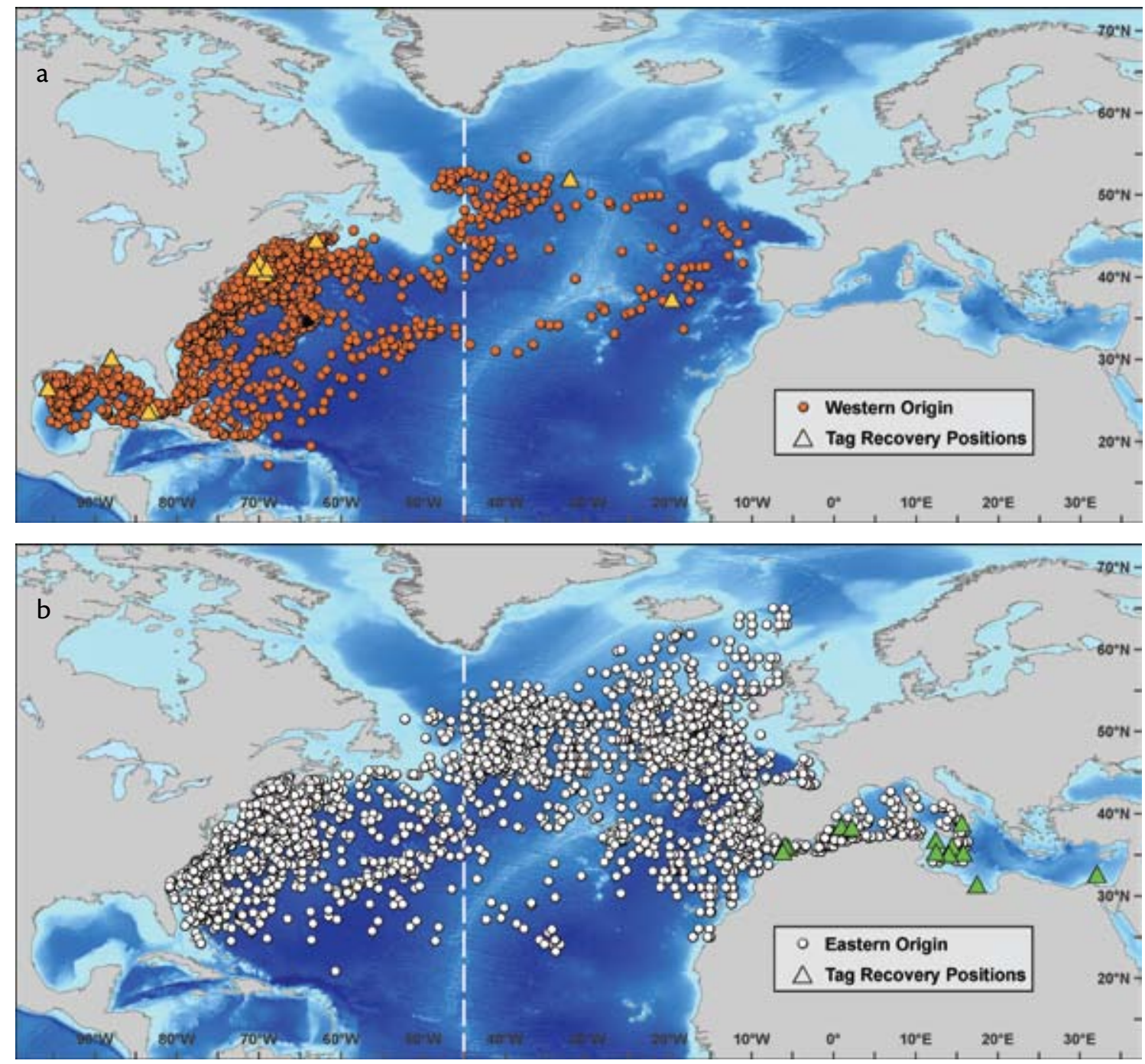

Figure 2. (a) Positions of bluefin tuna classified as western breeders tagged at three western Atlantic locations during 1996-2008. Orange circles represent locations based on deployment positions, light- and SST-based geolocation estimates, and PAT tag satellite endpoint positions. Yellow triangles represent recapture locations of western Atlantic-tagged fish. (b) Positions of bluefin tuna classified as eastern breeders tagged at three western Atlantic locations during 1996-2008. White circles represent locations, determined as before, with green triangles representing recapture locations.

combination with accurate on-board clock measurements of the times of local noon and midnight. Standard astronomical equations are then used to calculate position. Subsequently, latitude estimates are improved by comparing tag-based measurements of sea surface temperature (SST) with satellite-derived measurements of SST as a function of longitude.

By using these geolocation estimates to track the migrations of hundreds of bluefin tuna, the TAG project has demonstrated that there are at least two populations in the North Atlantic sharing common foraging areas but utilizing distinct breeding areas in the Gulf of Mexico and Mediterranean Sea. The tracking data show that adolescent fish from both management units mix extensively in the foraging areas on both sides of the Atlantic but upon maturation return to their respective breeding areas to spawn (Figure 2a, b) (Block et al., 2005). The level of mixing estimated from the tracking studies is higher than that assumed by the ICCAT stock assessment models used in setting management unit quotas (Block et al., 2001, 2005; Kurota et al., in press). The tracking data thus suggest that fisherman operating under the higher quotas in the eastern Atlantic have been undermining the quotas and fishery recovery plan in the western Atlantic. These data also suggest that ICCAT assessments in the western Atlantic have been conducted on a mixed population with many Mediterraneanspawned, eastern Atlantic fish counted among the catch. Current TAG efforts 
are underway to combine the tracking results with recent findings from genetic (Carlsson et al., 2007; Boustany et al., 2008) and otolith (Rooker et al., 2008) studies to develop spatially and temporally explicit models for better assessing the numerical abundances, residence patterns, and mixing of the two stocks in each management unit (Kurota et al., in press). This line of research provides a clear example of how the results from fish tracking studies can have direct implications for managing international fisheries for highly migratory species and setting policy on an ocean-basin scale.

In addition to providing ambient light data for establishing migratory movements, electronic tags also archive internal and environmental data that are useful for inferring other aspects of tuna behavioral and physiological ecology (Block, 2005; Teo et al., 2007a, 2007b). By observing the ocean environment from an individual's perspective, new insights can be gained about the challenges animals experience on spatial and temporal scales relevant to their daily ambits. The value of such a perspective is especially apparent in bluefin tuna, which employ remarkable physiological and behavioral adaptations to expand their thermal niche.

To illustrate this point, recent TAG results show that adolescent bluefin tuna undertake spring migrations between their winter foraging areas in the coastal waters of the Carolinas and their summer foraging areas at higher latitudes by transiting the slope waters between the Gulf Stream's north wall and the continental shelf. Largely confined between the $15^{\circ}-20^{\circ} \mathrm{C}$ sea surface temperature (SST) isotherms (Figure 3a), these migrating tuna commonly exploit prey- a
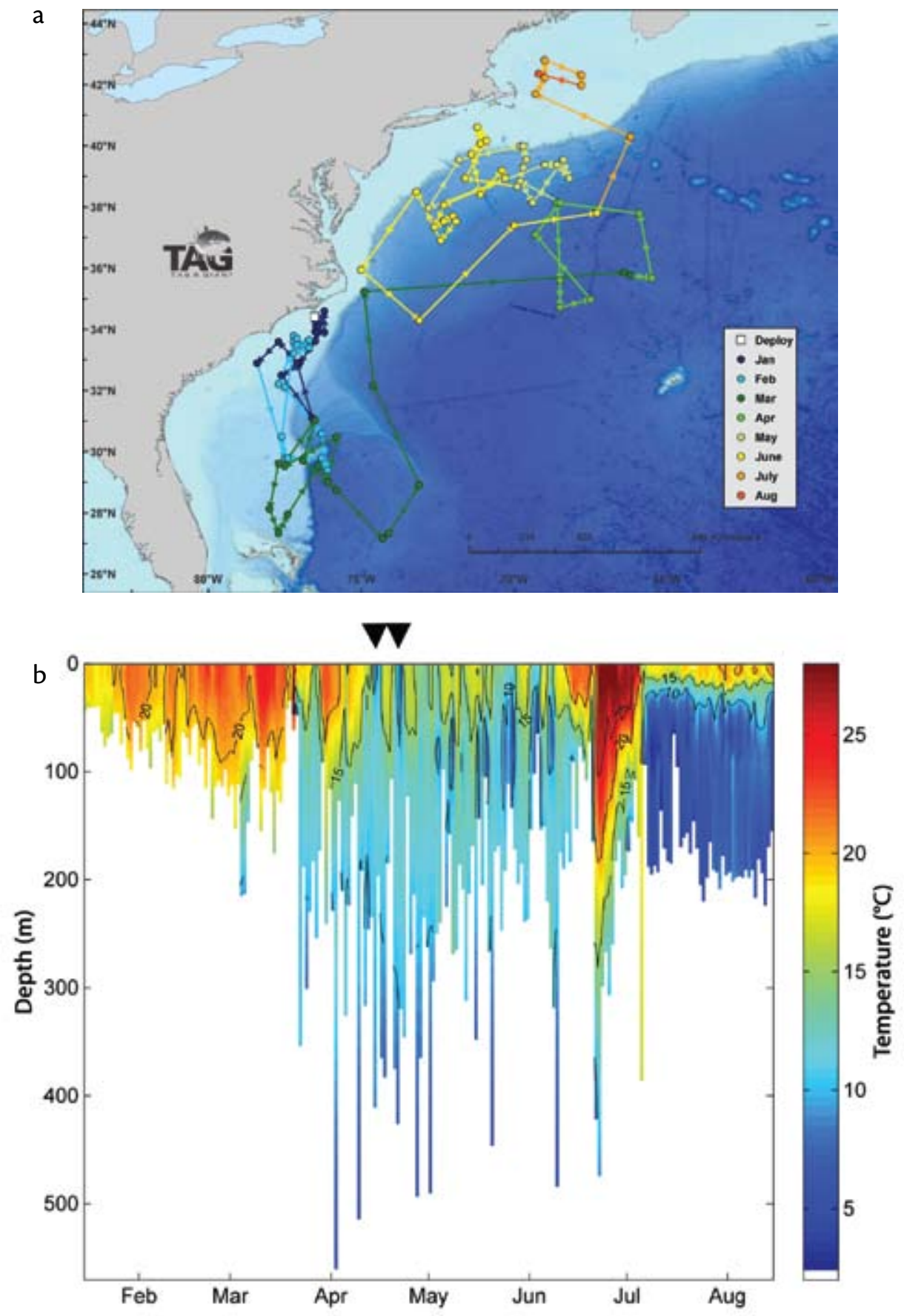

Figure 3. (a) Track for an Atlantic bluefin tuna fitted with an archival tag during January 2003 and recaptured during December 2004. (b) Ambient water temperatures experienced by the fish during the January-August 2003 period as a function of depth and calendar day. Vertical bars show daily tag-collected temperature-depth profiles, with the bottom of each bar indicating the maximum depth reached that day. During the early portion of the deployment, the fish occupied warm and well-mixed waters near the North Carolina tagging grounds and farther south. During late March, the fish moved northward and spent late April-June in the vicinity of the north wall of the Gulf Stream, in association with the $15-20^{\circ} \mathrm{C} \mathrm{SST}$ isotherms. During this period, the temperature-depth record also shows evidence of the fish making excursions of one or more days into cold waters beyond the $15^{\circ} \mathrm{C} \mathrm{SST} \mathrm{isotherm} \mathrm{(examples}$ of such excursions are indicated by arrows), before returning to warmer waters. During late June, the fish moved south into the warmer waters of the Gulf Stream, and then it moved up into the highly stratified waters of the Gulf of Maine during July. 
rich fronts along the edges of their thermal niche. However, once richer foraging areas are reached, the tuna often make short-term excursions into colder waters, beyond the $15^{\circ}$ isotherm, presumably to exploit the more abundant prey found there (Figure 3b). The unique cardiovascular system of bluefin tuna enables them to exploit foraging opportunities that would otherwise be thermally off limits to most subtropical predators (Blank et al., 2004).

Although physiological specializations may permit exploitation of a broader thermal niche, thereby providing bluefin tuna with obvious advantages for foraging, such enhancements may not be sufficient to buffer them from future climate-associated changes in oceanographic conditions. It has been reported that natural modes of climate variability, such as the North Atlantic Oscillation (NAO), are associated with shifts in the location where the Gulf Stream separates climate-change scenarios, the separation point and trajectory of the Gulf Stream's north wall are predicted to shift to the south of their climatological mean positions. Under other scenarios, changes in Arctic climate are expected to alter circulation patterns in the Northwest Atlantic, leading to a cooling and freshening of shelf and slope waters from the tail of the Grand Banks to the Gulf of Maine (Greene et al., 2008). Such changes could alter prey distributions or place foraging grounds currently exploited by bluefin tuna outside of their thermal tolerance range. With climate-associated constraints on their ecology, bluefin tuna might be expected to alter their migration patterns and use of important foraging areas. Stock assessment methods that rely on repeated sampling year after year at specific locations would be compromised by such changes in bluefin tuna distributions.

In addition to foraging excursions and frontal regions of mesoscale eddies spun off the Loop Current (Teo et al., 2007a,b). When these large, endothermic fish, which can weigh over $600 \mathrm{~kg}$, enter the Gulf, they face thermoregulatory challenges much greater than those experienced in the North Atlantic. Recent physiological studies show that the cardiac demands on bluefin tuna can lead to thermal stress at the higher temperatures typical of their breeding areas (Castilho et al., 2007; Teo et al., 2007a). The tuna exhibit deep-diving behavior in the Gulf, presumably for thermoregulatory cooling, prior to and after spawning. However, tagging data reveal that this behavior is altered during the spawning phase, with shallower dives occurring throughout the day and actual spawning thought to occur in the warm surface waters at night (Teo et al., 2007a, 2007b). Although there are clearly adaptive advantages to spawning at the surface, the potential for thermal stress may constrain the length of the spawning period as well as overall residence times in the Gulf.

Recent analyses of TAG tracking and satellite data sets demonstrate that certain remote-sensing data products, especially SST and sea surface height, can be used to predict bluefin breeding areas (Teo et al., 2007b). The combination of TAG and remote-sensing data are being used to develop models for forecasting the locations of breeding areas, spawning-period lengths under different environmental conditions, and overall residence times in the Gulf (recent work of author Block and Steven Teo, University of California, Davis). Such forecasting models have the potential to contribute to both operational and impactassessment conservation oceanography. 


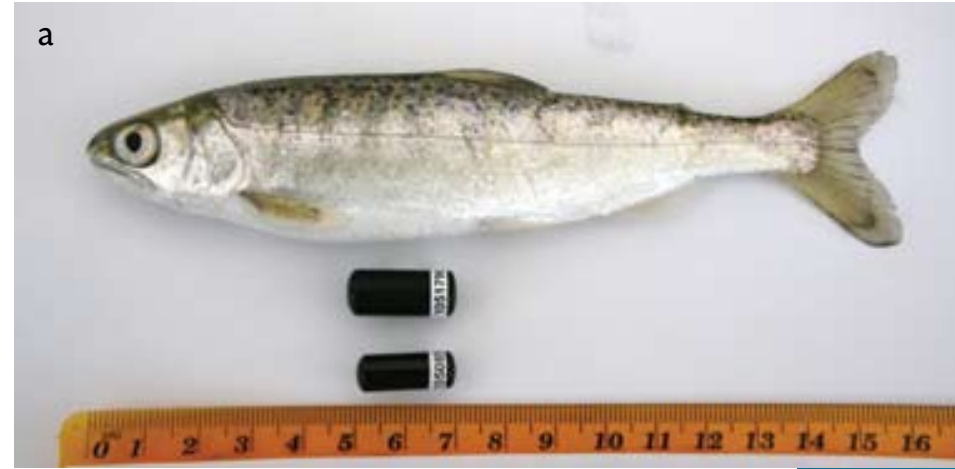

Figure 4. (a) Relative sizes of acoustic tags and a juvenile salmon. (b) Surgical implantation of acoustic tag.

Operationally, by assimilating real-time satellite data into these models, nearreal-time management decisions could be made to restrict fishing efforts in sensitive bluefin breeding areas. Although there has been an international fishing moratorium on bluefin tuna in the Gulf for over two decades, their bycatch in long-line gear set for other species remains one of the greatest conservation threats to the western Atlantic stock. In terms of impact assessment, the forecasting models could be used to assess the potential effects of climate warming on the spatial and temporal distributions of suitable bluefin breeding areas in the Gulf. They may also enable us to predict shifts in the arrival and departure times of the spawning population depending upon the environmental conditions of a given year.

\section{POST Project}

Salmonid species provide the basis for some of the most valuable commercial and recreational fisheries along the west coast of North America. Being anadromous fishes (fish that migrate from the ocean to freshwater to spawn), salmon face challenges to their survival in both freshwater and marine environments. Unlike tuna, which are exposed to fishing mortality later in life and few other anthropogenic threats earlier on, salmon run a gauntlet of anthropogenic challenges throughout their lifetimes. Threats to salmon survival in freshwater involve primarily habitat alteration and destruction, including the damming of rivers for hydroelectric power generation. Hydroelectric dams can impede the downstream migration of juveniles to the coastal ocean as well as the upstream return of mature fish to their spawning grounds. The ecology of salmon in the ocean is poorly understood (Brodeur et al., 2000), and there is considerable controversy about which is more important to recruitment variability, mortality in freshwater or mortality in the marine environment. Finding the answer to this question has critical policy implications as two decades of declining salmon runs in California, Oregon, and Washington have been blamed on everything from climate-associated regime shifts (Mantua et al., 1996) to anthropogenic impacts ranging from dams to logging to pollution to overfishing (NRC, 1996; Ruckelshaus et al., 2002).

Salmonid studies in the POST project rely on surgically implanted tags (Figure 4a, b), which transmit uniquely encoded acoustic signals that are sensed and archived by autonomous, passive listening receivers on the seafloor (Welch et al., 2003, 2004; Melnychuk et al., 2007). By 2010, POST plans to deploy a permanent array of cross-shelf receiver lines at strategic locations along the North American west coast from California to the Aleutian Islands. The pilot array has been deployed each year since 2004 and extends over 2,500 km along the coasts 


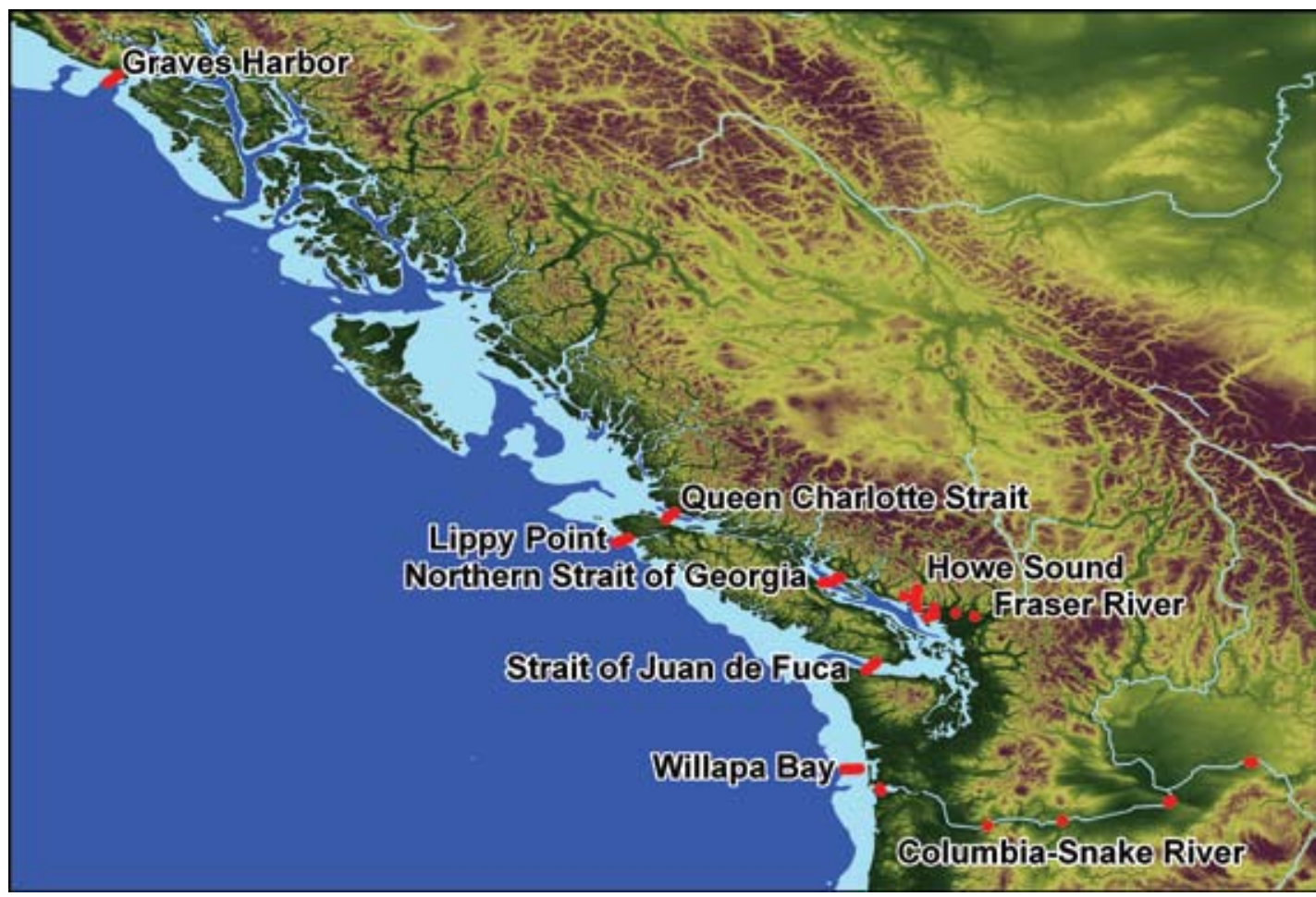

Figure 5. The current POST (Pacific Ocean Shelf Tracking) acoustic array extending over 2,500 km along the coasts of southeast Alaska, British Columbia, Washington, and Oregon.

of southeast Alaska, British Columbia, Washington, and Oregon (Figure 5). Although the initial focus of the POST project has been on salmonid species, the pilot array is equally capable of tracking the along-shelf migrations of numerous other marine species. For example, the array has already revealed the previously unknown and extensive trans-border movements of white and green sturgeon (tagged by other investigators not originally associated with the POST project) from central California to British Columbia (Welch et al., 2006; Lindley et al., 2008).

Prior to implementation of the permanent, year-round array, the POST project conducted studies with the pilot array from 2004 to 2006 to establish both the technical performance of a largescale telemetry system and to document freshwater and marine migration and survival patterns of both juvenile and adult salmon. Results from these pilot studies provided the first opportunity to compare relative freshwater and marine survival rates of juveniles and returning adults from a number of different Pacific salmon species and stocks (Crossin et al., 2007, 2008; Melnychuk et al., 2007; Cooke et al., 2008; Welch et al., 2008).

One fundamental, but currently unresolved, question is whether juvenile salmon mortality is of greater importance in freshwater or in the marine environment. The conventional wisdom among most salmon biologists and managers has been that juvenile survival is greater in the marine environment than in freshwater, and therefore conservation efforts ignoring the role of the ocean can be successful. However, results from the POST pilot studies indicate that, although there were some differences among species and stocks and between years, survival estimates for tagged juveniles in freshwater were typically higher than those observed in the marine environment. This surprising finding, which runs counter to the conventional wisdom, suggests that some of our most basic assumptions about the ecology of salmon may need to be reconsidered.

If the conventional wisdom about juvenile survival in freshwater is called into question, then what other surprises might the POST telemetry system reveal? Welch et al. (2008) recently reported results from a study comparing juvenile survival of chinook and steelhead out of the Snake-Columbia River system, which has eight dams, with juvenile survival of these same species out of the 


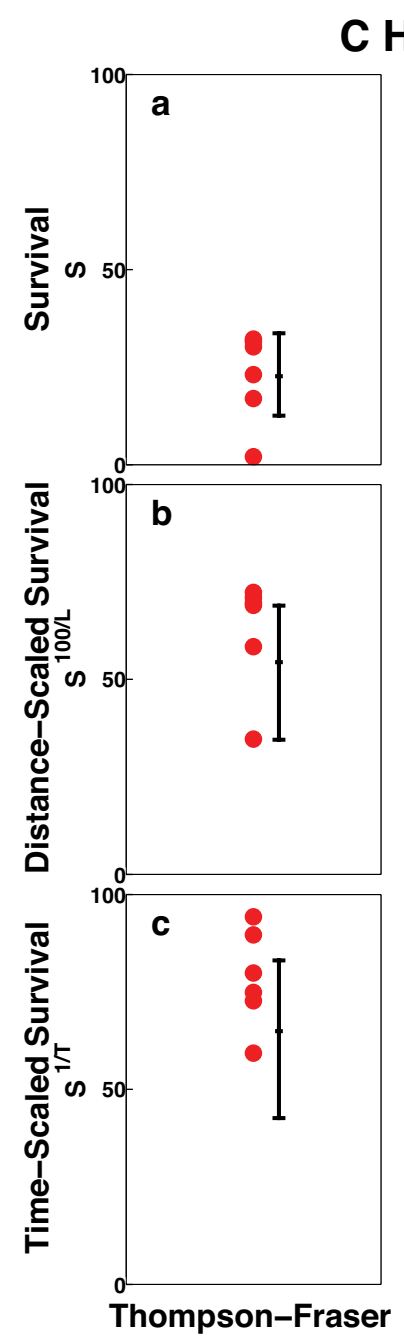

CHINOOK

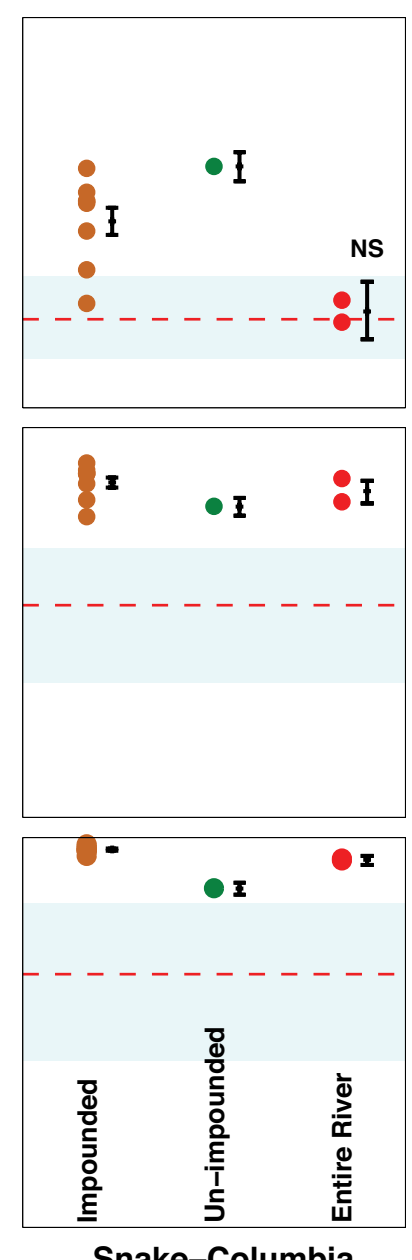

Snake-Columbia
S TEELHEA D

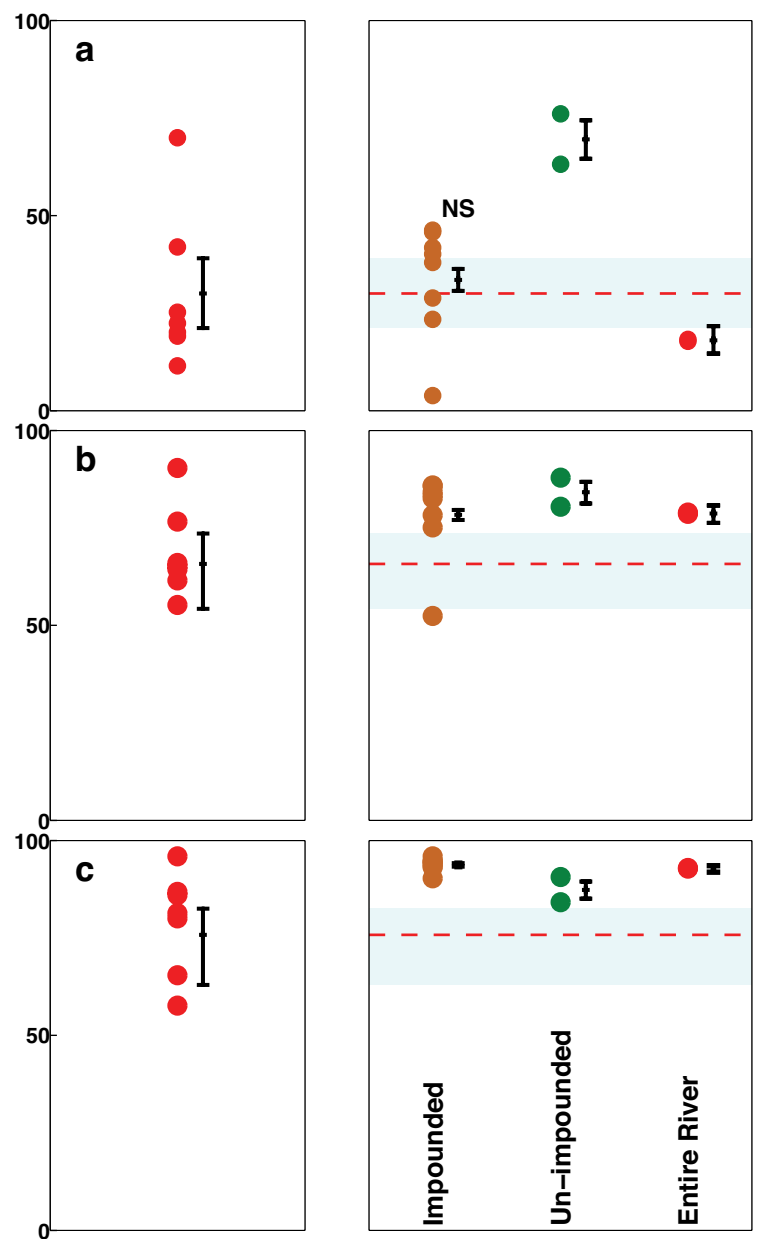

Thompson-Fraser

\section{Snake-Columbia}

Figure 6. Survival estimates for Thompson and Snake River spring chinook and steelhead. (a) Estimated survival. (b) Survival scaled by100 km traveled (100/L). (c) Survival scaled by migration day (1/T). For each species, the left panel shows the survival of different Thompson River stocks released to migrate down to the Fraser River mouth; the right panel shows the survival of Snake River stocks migrating down three sections of the Columbia River hydropower system: impounded (upper river; eight dams), unimpounded (lower river; undammed), and entire river. The vertical bar to the right of each group of individual survival estimates (circles) shows the mean survival and 95\% confidence interval for the group, averaged across all available data. The blue band and dashed red line shows the mean and $95 \%$ confidence interval for the Fraser River survival in comparison to the Columbia. In all survival comparisons, Snake-Columbia River estimates were significantly different from Thompson-Fraser estimates at the $95 \%$ confidence level unless indicated by NS. For further details, see the original Figure 3 from Welch et al. (2008), from which this figure was modified. Because the POST array was deployed only in the lower Fraser River, it is not possible to break out survival by river section, as can be done for the Columbia River data.

Fraser River, which has no dams. The results demonstrated that overall survival out of the Snake-Columbia River system, despite its dams, was comparable (Figure 6). Furthermore, when the survival estimates were scaled by distance traveled or time spent in each environment, survival was actually higher in the
Snake-Columbia River system. Perhaps even more surprising, scaled survival estimates were actually higher for both species in the dammed stretch of the Snake-Columbia River system than in the Fraser River. These findings should raise important questions among fisheries managers about why endangered
Snake-Columbia River stocks have such poor returns from the ocean despite reasonable juvenile survival when migrating out to sea. Prior to the POST project, it had been assumed that the poor returns in these stocks were a consequence of dam-associated mortality during the juvenile downstream migration (Welch 
et al., 2008). These findings, as well as those described previously, suggest that fisheries managers and policymakers may want to turn their attentions out to sea in order to more fully understand the ecological processes regulating salmon population dynamics.

The consequences of basing management and policy decisions on faulty assumptions or inadequate scientific knowledge can be costly. Some preliminary POST results from the Columbia River highlight another potential mismatch between the actual ecological dynamics of salmon and those typically assumed by fisheries managers. In the past, it was assumed that juvenile salmon survival was higher during migration through the undammed lower portion of the Columbia River and coastal ocean than during migration through the dammed upper portion of the river. To mitigate for losses at the dams, a major management program was developed to physically transport smolts around the dams using barges specifically constructed for the task. The managers, however, had no knowledge of juvenile salmon survival in the ocean, and thus it was assumed that salmon were better off once they were deposited below the dams nearer to the estuary and ocean. Although barging has reduced the time spent by smolts migrating down the river from three weeks to roughly two days, thus avoiding the roughly $50 \%$ inriver mortality incurred by the time the juvenile salmon reached the last dam, the anticipated doubling of adult returns has not been realized (Muir et al., 2006). This finding was used to argue that barging was not effective possibly because it increases the stress experienced by juveniles after release, thereby negating any potential benefits derived by avoiding the dams (Congleton et al. 2000). However, another interpretation is equally, if not more, plausible. By comparing juvenile survival estimates to data from the various POST subarrays and scaling them by time (Figure 7), one can make quantitative arguments why barging smolts past the dams may not yield higher numbers of returning adults (recent work of author Rechisky and colleagues). Although barging reduces time spent by smolts in the dammed upper portion of the Columbia River, it does so by increasing the time spent in the lower river and in the coastal ocean. Survival estimates are highest in the lower river, intermediate in the upper river, and lowest in the coastal ocean (Figure 7a). However, when survivorship is scaled by the mean time spent to reach each subarray (Figure 7b), the surprising result is obtained that survival rates may be highest in the dammed upper portion of the river! Because barging would only be beneficial when juveniles are moved from a high- to a low-mortality environment, the ineffectiveness of this management approach can be readily explained using actual field data. This example illustrates the potential cost effectiveness of using the POST telemetry system to test scientific assumptions prior to embarking on expensive experiments in fisheries management.

Similar to the TAG project, the POST project will enable scientists to tackle many issues important to fisheries management that could not be addressed previously. For the first time, scientists will be able to document the extensive migration pathways for different salmonid stocks and estimate survivorship along various segments of these pathways. Over time, it should become possible to determine how climate and various anthropogenic impacts affect these migration pathways and their associated survivorship estimates. In addition, the POST project is well suited for experimental hypothesis testing in the wild. For example, the question of whether hatchery-reared salmon are as fit as wild ones is controversial, with many implications for management decisions ranging from stock-rebuilding efforts to endangered species designation (Myers et al., 2004). With simultaneous, controlled, and replicated releases of hatchery-reared and wild juveniles, it will be possible to determine experimentally their relative survivorship in both freshwater and marine environments. Similar experimental studies can be envisioned for studying the impacts of hatchery-associated sea lice on wild stocks of Pacific salmon (Krkošek et al., 2007). It will be a major advance when properly controlled and replicated field experiments constitute the best available science to inform fisheries management decisions.

\section{CONCLUDING REMARKS}

Throughout the history of human civilization, society has never posed as great a threat as it does now to the sustainability of living resources in the sea. In the United States, this threat has been recognized, and two commissions have released reports since the turn of the millennium that offer many policy recommendations (PEW Oceans Commission, 2003; US Commission on Ocean Policy, 2004). When these recommendations transition into new policies and laws, it will be the responsibility of local, state, and federal resource managers to implement them. To be successful, 
management decisions are supposed to be made only after managers have evaluated a wide range of scientific and socioeconomic factors before deciding upon an appropriate course of action. Because science is only one factor contributing to the decision-making process, scientific advances by themselves are not sufficient for solving the many problems faced in fisheries management. Nevertheless, it is safe to assert that management decisions will be more successful when fisheries managers are informed by the best available science.

In this paper, we suggest that the stage is set for a transformational change in the science underlying fisheries management. The new technologies emerging within the ocean science community offer a perspective for studying the behavioral, physiological, and population ecology of fish that is truly unprecedented. However, to be of practical use to fisheries managers, the ecological insights gained by the scientific community must be transitioned into operational data products and models that are readily accessible. Local, state, and federal agencies charged with the responsibility of managing fisheries must work with and help support the scientists pushing the limits of conservation oceanography. The goal of sustainable fisheries is an elusive one; a concerted effort by scientists and managers will be critical to overcoming the daunting challenges ahead.

\section{ACKNOWLEDGMENTS}

The concept of conservation oceanography was inspired by the challenge laid down by Nancy Knowlton in her plenary talk at the $2006 \mathrm{AGU} / \mathrm{ASLO} /$ TOS Ocean Sciences Meeting in
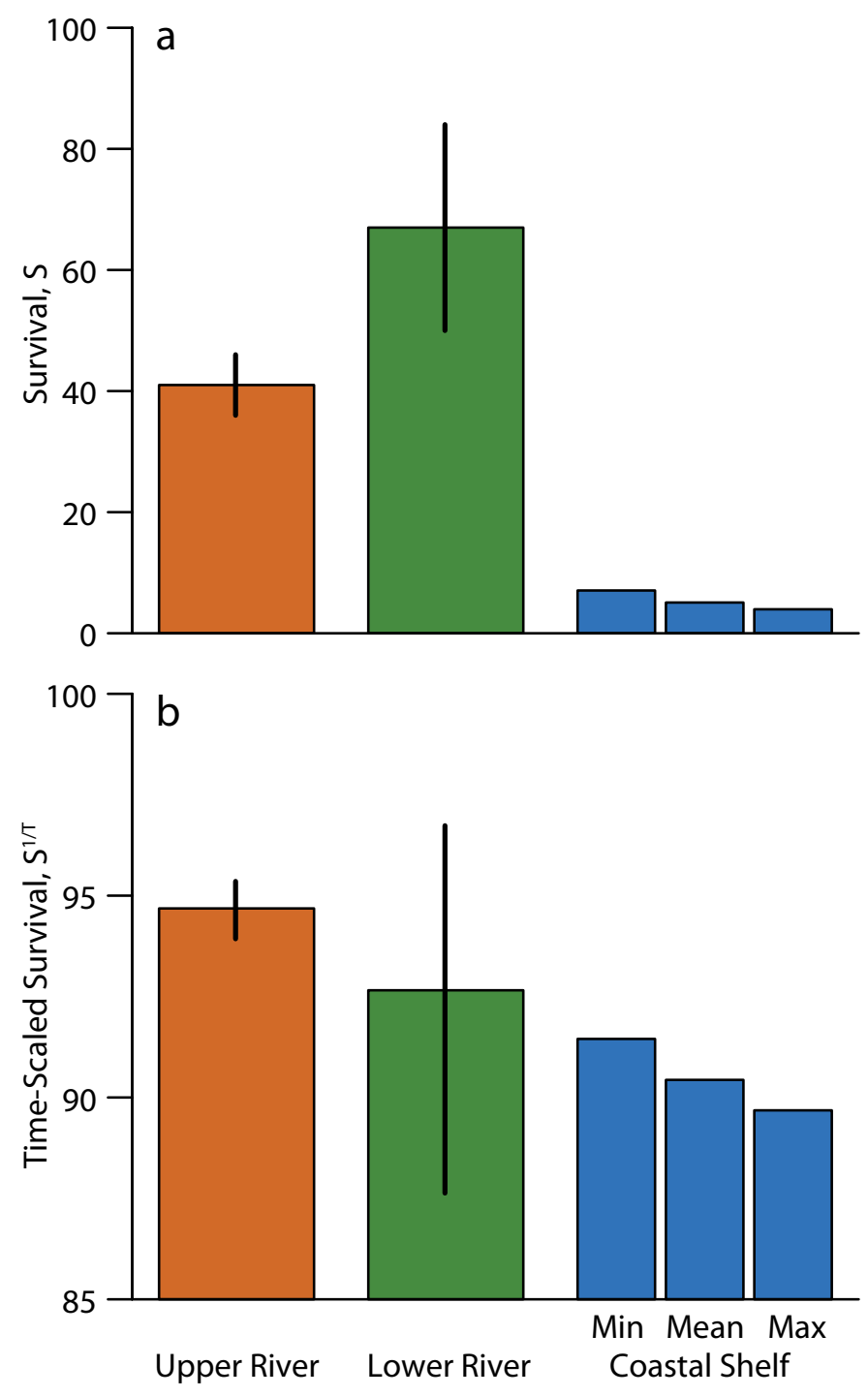

Figure 7. (a) 2006 survival probability estimates in the dammed upper portion of the Columbia River, the undammed lower portion of the river, and the coastal shelf. (b) Survival estimates as above but scaled by migration day $(1 / T)$. Survival probabilities in the upper and lower river were estimated with the Cormack Jolly Seber mark-recapture model, which jointly estimates survival and detection probabilities. This model could not be used to estimate coastal shelf survival probability directly due to limited detections in Alaska. Therefore, we estimated the long-shelf survival probability using the following three assumptions: (1) that the detection probability of the Lippy Point subarray was equal to the mean detection probability (MEAN) observed at Willapa Bay (where detection efficiency could be estimated accurately), (2) that the detection probability of the Lippy Point subarray was equal to the lower $95 \%$ confidence limit on detection probability (MIN) observed at Willapa Bay, and (3) that the detection probability of the Lippy Point subarray was equal to the upper $95 \%$ confidence limit on detection probability (MAX) observed at Willapa Bay. Irrespective of the detection probability assumed, the conventional wisdom that survival per day is better in the coastal ocean than in freshwater is not supported. Figure 5 shows the locations of the Lippy Point and Willapa Bay subarrays. (See recent work of author Rechisky and colleagues for further details.) 
Honolulu, HI. This paper is the product of a collaboration among several of the authors while preparing for a special symposium entitled "The Emergence of Conservation Oceanography" held at the 2007 AAAS Meeting in San Francisco, CA. The Tag-A-Giant project has been supported by the TAG, Packard, Lenfest, MacArthur, Disney, Marine Ventures, Gordon and Betty Moore, and Monterey Bay Aquarium foundations and NOAA. The POST project has been supported by the Gordon and Betty Moore Foundation, the Sloan Foundation, the Bonneville Power Administration, the Northwest Power Planning and Conservation Council, and the US Army Corps of Engineers. Support for CHG's involvement was provided by the Office of Naval Research and the US Global Ocean Ecosystems (GLOBEC) Program. This paper is a contribution to the Census of Marine Life and GLOBEC contribution 618. 迎

\section{REFERENCES}

Biuw, M., L. Boehme, C. Guinet, M. Hindell, D. Costa, J.-B. Charrassin, F. Roquet, F. Bailleul, M. Meredith, and others. 2007. Variations in behavior and condition of a Southern Ocean top predator in relation to in situ oceanographic conditions. Proceedings of the National Academy of Sciences of the United States of America 104:13,705-1,3710.

Blank, J.M., J.M. Morrissette, A.M. LandeiraFernandez, S.B. Blackwell, T.D. Williams, and B.A. Block. 2004. In situ cardiac performance of Pacific bluefin tuna hearts in response to acute temperature change. Journal of Experimental Biology 207:881-890

Block, B.A. 2005. Physiological ecology in the 21st century: Advancements in biologging science. Integrative and Comparative Biology 45:305-320.

Block, B.A., D.P. Costa, G.W. Boehlert, and R.E. Kochevar. 2003. Revealing pelagic habitat use: The Tagging of Pacific Pelagics program. Oceanologica Acta 25:255-266.

Block, B.A., H. Dewar, S.B. Blackwell, T.D. Williams, E.D. Prince, C.J. Farwell, A. Boustany, S.L.H. Teo, A. Seitz, A. Walli, and D. Fudge. 2001. Migratory movements, depth preferences, and thermal biology of Atlantic bluefin tuna. Science
293:1,310-1,314.

Block, B.A., H. Dewar, C. Farwell, and E.D. Prince. 1998. A new satellite technology for tracking the movements of Atlantic bluefin tuna. Proceedings of the National Academy of Sciences of the United States of America 95:9,384-9,389.

Block, B.A., S.L.H. Teo, A. Walli, A. Boustany, M.J.W. Stokesbury, C.J. Farwell, K.C. Weng, H. Dewar, and T.D. Williams. 2005. Electronic tagging and population structure of Atlantic bluefin tuna. Nature 434:1,121-1,127.

Boelhert, G.W., D.P. Costa, D.E. Crocker, P. Green, T. O'Brien, S. Levitus, and B.J. LeBoeuf. 2001. Autonomous pinniped environmental samplers: Using instrumented animals as oceanographic data collectors. Journal of Atmospheric and Oceanic Technology 18:1,882-1,893.

Boustany, A.M., C.A. Reeb, and B.A. Block. 2008. Mitochondrial DNA and electronic tracking reveal population structure of Atlantic bluefin tuna (Thunnus thynnus). Marine Biology 156:13-24.

Brodeur, R.D., W.T. Peterson, G.W. Boehlert, E. Casillas, M.H. Schiewe, M.B. Eldridge, S.T. Lindley, J.H. Helle, and W.R. Heard. 2000. A coordinated research plan for estuarine and ocean research on Pacific salmon. Fisheries 25(6):7-16.

Carlsson, J., J.R. McDowell, J.E.L. Carlsson, and J.E. Graves. 2007. Genetic identity of YOY bluefin tuna from the eastern and western Atlantic spawning areas. Journal of Heredity 98:23-28.

Castilho, P.C., A.M. Landeira-Fernandez, J. Morrissette, and B.A. Block. 2007. Elevated $\mathrm{Ca}^{2+}$ ATPase (SERCA2) activity in tuna hearts: Comparative aspects of temperature dependence. Comparative Biochemistry and Physiology Part A 148:124-132.

Congleton, J.L., W.J. LaVoie, C.B. Schreck, and L.E. Davis. 2000. Stress indices in migrating juvenile chinook salmon and steelhead of wild and hatchery origin before and after barge transportation. Transactions of the American Fisheries Society 129:946-961.

Cooke, S.J., S.G. Hinch, A.P. Farrell, D.A. Patterson, K. Miller-Saunders, D.W. Welch, M.R. Donaldson, K.C. Hanson, G.T. Crossin, M.T. Mathes, and others. 2008. Developing a mechanistic understanding of fish migrations by linking telemetry with physiology, behavior, genomics and experimental biology: An interdisciplinary case study on adult Fraser River sockeye salmon. Fisheries 33(7):321-338

Costa, D.P. 1993. The secret life of marine mammals: Novel tools for studying their behavior and biology at sea. Oceanography 6(3):120-128.

Costa, D.P., J.M. Klinck, E.E. Hofmann, M.S. Dinniman, and J.M. Burns. 2008. Upper ocean variability in west Antarctic Peninsula continental shelf waters as measured using instrumented seals. Deep-Sea Research Part II 55:323-337.

Crossin, G.T., S.G. Hinch, S.J. Cooke, D.W. Welch, S.D. Batten, D.A. Patterson, G. Van Der Kraak, J.M. Shrimpton, and A.P. Farrell. 2007. Behaviour and physiology of sockeye salmon homing through coastal waters to a natal river. Marine Biology 152:905-918.

Crossin, G.T., S.G. Hinch, S.J. Cooke, D.W. Welch, D.A. Patterson, S.R.M. Jones, A.G. Lotto, R.A. Leggatt, M.T. Mathes, J.M. Shrimpton, and others. 2008. Exposure to high temperature influences the behaviour, physiology, and survival of sockeye salmon during spawning migration. Canadian Journal of Zoology 86:127-140.

Cury, P.M., Y.-J. Shin, B. Planque, J.M. Durant, J.-M. Fromentin, S. Kramer-Schadt, N.C. Stenseth, M. Travers, and V. Grimm. 2007. Ecosystem oceanography for global change in fisheries. Trends in Ecology \& Evolution 23:338-346.

Essington, T.E., A.H. Beaudreau, and J. Wiedenmann. 2006. Fishing through marine food webs. Proceedings of the National Academy of Sciences of the United States of America 103:3,171-3,175.

Frank, K.T, B. Petrie, N.L. Shackel, and J.S. Choi. 2006. Reconciling differences in trophic control in midlatitude marine ecosystems. Ecology Letters 9:1-10.

Gangopadhyay, A., P. Cornillon, and R.D. Watts. 1992. A test of the Parsons-Veronis hypothesis on the separation of the Gulf Stream. Journal of Physical Oceanography 22:1,286-1,301.

Gawarkiewicz, G., S. Monismith, and J. Largier. 2007. Observing larval transport processes affecting population connectivity: Progress and challenges. Oceanography 20(3):40-53.

Govoni, J.J. 2005. Fisheries oceanography and the ecology of early life histories of fishes: A perspective over fifty years. Scientia Marina 69:125-137.

Greene, C.H, and A.J. Pershing. 2007. Climate drives sea change. Science 315:1,084-1,085.

Greene, C.H., A.J. Pershing, T.M. Cronin, and N. Ceci. 2008. Arctic climate change and its impacts on the ecology of the North Atlantic. Ecology 89(11) Supplement S24-38.

Gunn, J., and B. Block. 2001. Advances in acoustic, archival and satellite tagging of tunas. Pp. 167-224 in Tuna: Physiology, Ecology and Evolution. B.A. Block and E.D. Stevens, eds, Academic Press, San Diego, CA.

Jackson, J.B.C., M.X. Kirby, W.H. Berger, K.A. Bjorndal, L.W. Botsford, B.J. Bourque, R.H. Bradbury, R. Cooke, J. Erlandson, J.A. Estes, and others. 2001. Historical overfishing and the recent collapse of coastal ecosystems. Science 293:629-637.

Kendall, A.W., and G.J. Duker. 1998. The development of recruitment fisheries oceanography in the United States. Fisheries Oceanography 7:69-88.

Kitagawa, T., H. Nakata, S. Kimura, T. Itoh, S. Tsuji, and A. Nitta. 2000. Effect of ambient temperature on the vertical distribution and movement of Pacific bluefin tuna Thunnus thynnus orientalis. Marine Ecology Progress Series 206:251-260.

Krkošek, J.S. Ford, A. Morton, S. Lele, R.A. Myers, M.A. Lewis. 2007. Declining wild salmon populations in relation to parasites from farm salmon. Science 318:1,772-1,775. 
Kurota, H., M.K. McAllister, G.L. Lawson, J.I. Nogueira, S.L.H. Teo, and B.A. Block. In press. A sequential Bayesian methodology to estimate movement and exploitation rates using electronic and conventional tag data: Application to Atlantic bluefin tuna (Thunnus thynnus). Canadian Journal of Fisheries and Aquatic Sciences.

Laidre, K.L., and M.P. Heide-Jorgensen. 2007. Using narwhals as ocean-observing platforms in the high Arctic. Oceanography 20(4):30-35.

Larkin, P.A. 1977. An epitaph for the concept of maximum sustainable yield. Transactions of the American Fisheries Society 106:1-11.

Lindley, S.T., M.L. Moser, D.L. Erickson, M. Belchik, D.W. Welch, E.L. Rechisky, J.T. Kelly, J. Heublein, A.P. Klimley. 2008. Marine migration of North American green sturgeon. Transactions of the American Fisheries Society 137:182-194.

Lotze, H.K., H.S. Lenihan, B.J. Bourque, R.H. Bradbury, R.G. Cooke, M.C. Kay, S.M. Kidwell, M.X. Kirby, C.H. Peterson, and J.B.C. Jackson. 2006. Depletion, degradation, and recovery potential of estuaries and coastal seas. Science 312:1,806-1,809.

Mantua, N.J., S.R. Hare, Y. Zhang, J.M. Wallace, and R.C. Francis. 1996. A Pacific interdecadal climate oscillation with impacts on salmon production. Bulletin of the American Meteorological Society 78:1,069-1,079.

Melnychuk, M.C., D.W. Welch, D.J. Walters, and V. Christensen. 2007. Riverine and early ocean migration and mortality patterns of juvenile steelhead trout (Oncorhynchus mykiss) from the Cheakamus River, British Columbia. Hydrobiologia 582:55-65.

MERCINA. 2001. Oceanographic responses to climate in the Northwest Atlantic. Oceanography 14(3):76-82.

Miller, T.J. 2007. Contribution of individual-based coupled physical-biological models to understanding recruitment in marine fish populations. Marine Ecology Progress Series 347:127-138.

Muir, W.D., D.M. Marsh, B.P. Sandford, S.G. Smith, and J.G. Williams. 2006. Post-hydropower system delayed mortality of transported Snake River stream-type chinook salmon: Unraveling the mystery. Transactions of the American Fisheries Society 135:1,523-1,534

Myers, R.A., S.A. Levin, R. Lande, F.C. James, W.W. Murdoch, and R.T. Paine. 2004. Hatcheries and endangered salmon. Science 303:1,980.

Myers, R.A., and B. Worm. 2003. Rapid worldwide depletion of predatory fish communities. Nature 423:280-283.

Nielsen, A., K.A. Bigelow, M.K. Musyl, and J.R. Sibert. 2006. Improving light-based geolocation by including sea surface temperature. Fisheries Oceanography 15:314-325.

NRC. 1996. Upstream: Salmon and Society in the Pacific Northwest. National Academies Press, Washington, DC, 452 pp.

Pauly, D. 1995. Anecdotes and the shifting baseline syndrome of fisheries. Trends in Ecology \&
Evolution 10:430.

Pauly, D., V. Christensen, J. Daisgaard, R. Froese, and F. Torres Jr. 1998. Fishing down marine food webs. Science 860-863.

Pauly, D., V. Christensen, S. Guénette T.J. Pitcher, U.R. Sumaila, C.J. Walters, R. Watson and D. Zeller. 2002. Toward sustainability in world fisheries. Nature 418:689-695.

Perry, M.J., and D.L. Rudnick. 2003. Observing the ocean with autonomous and Lagrangian platforms and sensors: The role of ALPS in sustained ocean observing systems. Oceanography 16(4):31-36.

PEW Oceans Commission. 2003. America's Living Oceans: Charting a Course for Sea Change. A Report to the Nation. PEW Oceans Commission, Arlington, VA.

Reid, P.C., J.M. Colebrook, J.B.L. Matthews, and J. Aiken. 2003. The Continuous Plankton Recorder: Concepts and history, from plankton indicators to undulating recorders. Progress in Oceanography 58:117-173.

Ricker, W.E. 1954. Stock and recruitment. Journal of the Fisheries Research Board of Canada 11:559-623.

Rooker, J.R., D.H. Secor, G. DeMetrio, R. Schloesser, B.A. Block, and J.D. Neilson. 2008. Natal homing and connectivity in Atlantic bluefin tuna populations. Science 31:742-744.

Rothstein, L.M., J.J. Cullen, M. Abbott, E.P. Chassignet, K. Denman, S.C. Doney, H. Ducklow, K. Fennel, M. Follows, D. Haidvogel, and others. 2006. Modeling ocean ecosystems: The PARADIGM Program. Oceanography 19(1):16-45.

Rozwadowski, H.M. 2002. The Sea Knows No Boundaries: A Century of Marine Science Under ICES. International Council for the Exploration of the Sea, Copenhagen, in cooperation with University of Washington Press, 448 pp.

Ruckelshaus, M.H., P. Levin, J.B. Johnson, and P.M. Kareiva. 2002. The Pacific salmon wars: What science brings to the challenge of recovering species. Annual Review of Ecology and Systematics 33:665-706.

Safina, C., and D.H. Klinger. 2007. Collapse of bluefin tuna in the western Atlantic. Conservation Biology 22:243-246.

Schaefer, M.B. 1954. Some aspects of the dynamics of populations important to the management of the commercial marine fisheries. Bulletin of the InterAmerican Tropical Tuna Commission 1:25-56.

Sibert, J., J. Hampton, P. Kleiber, and M. Maunder. 2006. Biomass, size, and trophic status of top predators in the Pacific Ocean. Science 314:1,773-1,776.

Sibert, J.R., and J. Nielsen, eds. 2001. Electronic Tagging and Tracking in Marine Fisheries. Kluwer Academic Publishers, The Netherlands, 484 pp.

Taylor, A.H., and J.A. Stephens. 1998. The North Atlantic Oscillation and the latitude of the Gulf Stream. Tellus 50A:134-142.

Teo, S.L.H., A. Boustany, S. Blackwell, A. Walli, K.C. Weng, and B.A. Block. 2004. Validation of geolocation estimates based on light level and sea surface temperature from electronic tags. Marine Ecology
Progress Series 283:81-98.

Teo, S.L.H., A. Boustany, and B.A. Block. 2007a. Oceanographic preferences of Atlantic bluefin tuna, Thunnus thynnus, on their Gulf of Mexico breeding grounds. Marine Biology 152:1,105-1,119.

Teo, S.L.H., A. Boustany, H. Dewar, M.J.W. Stokesbury, K. Weng, S. Beemer, A.C. Seitz, C.J. Farwell, E.D. Prince, and B.A. Block. 2007b. Annual migrations, diving behavior, and thermal biology of Atlantic bluefin tuna, Thunnus thynnus, on their Gulf of Mexico breeding grounds. Marine Biology 151:1-18.

US Commission on Ocean Policy. 2004. An Ocean Blueprint for the $21^{\text {st }}$ Century. Final Report. Washington, DC, 378 pp.

Welch, D.W., G.W. Boehlert, and B.R. Ward. 2003. POST: The Pacific Ocean salmon tracking project. Oceanologica Acta 25:243-253.

Welch, D.W., E.L. Rechisky, M.C. Melnychuk, A.D. Porter, C.J. Walters, S. Clements, B.J. Clemens, R.S. McKinley, and C. Schreck. 2008. Survival of migrating salmon smolts in large rivers with and without dams. PLoS Biology 6(10):e265, doi:10.1371/journal.pbio.0060265.

Welch, D.W., S. Turo, and S.D. Batten. 2006. Largescale marine and freshwater movements of white sturgeon. Transactions of the American Fisheries Society 135:140-143.

Welch, D.W., B.R. Ward, and S.D. Batten. 2004. Early ocean survival and marine movements of hatchery and wild steelhead trout (Oncorhynchus mykiss) determined by an acoustic array: Queen Charlotte Strait, British Columbia. Deep-Sea Research Part II 51:897-909.

Weng, K.C., P.C. Castilho, J.M. Morrissette, A.M. Landeira-Fernandez, D.B. Holts, R.J. Schallert, K.J. Goldman, and B.A. Block. 2005. Satellite tagging and cardiac physiology reveal niche expansion in salmon sharks. Science 310:104-106.

Werner, F.E., R.K. Cowen, and C.P. Paris. 2007. Coupled biological and physical models: Present capabilities and necessary developments for future studies of population connectivity. Oceanography 20(3):54-69.

Wilson, S.G., M.E. Lutcavage, R.W. Brill, M.P. Genovese, A.B. Cooper, and A.W. Everly. 2005. Movements of bluefin tuna (Thunnus thynnus) in the northwestern Atlantic Ocean recorded by pop up satellite archival tags. Marine Biology 146:409-423. 